\title{
Effect of Moisture Regime and Customized Fertilizer on Water Use Efficiency and Economics of Potato (Solanum tuberosum L.)
}

\author{
Mohammad Irfan*, B.N. Singh and Ghansyam Singh \\ Department of Agronomy NDUA \& T Kumarganj, Faizabad U.P.-224229, India \\ *Corresponding author
}

\begin{tabular}{|c|c|}
\hline & A B S T R A C T \\
\hline & \multirow{4}{*}{$\begin{array}{l}\text { A field experiment was conducted to study the "Effect of moisture regimes and } \\
\text { customized fertilizers on the performance of potato (Solanum tuberosum L.)" } \\
\text { during Rabi season of } 2010-11 \text { at Agronomy Research Farm, Narendra Deva } \\
\text { University of Agriculture \& Technology (Narendra Nagar), Kumarganj, Faizabad. } \\
\text { Highest WUE efficiency was recorded with } 6 \mathrm{~cm} \text { irrigation at } 1.0 \text { IW/CPE ratio } \\
\text { and customized fertilizer }\left(\mathrm{F}_{4}\right) \text {. The highest net return and benefit-cost ratio of Rs. } \\
79309.00 \mathrm{ha}^{-1} \text { and } 1.78 \text { were computed under treatment combination } \mathrm{I}_{2} \mathrm{~F}_{4}(6 \mathrm{~cm} \\
\text { irrigation at } 1.0 \mathrm{IW} / \mathrm{CPE} \text { ratio }+8: 18: 26: 1: 0.1: 6 \text { (N:P:K:Zn:B:S } 150: 67.5: \\
\left.97.5: 3.75: 0.37: 22.5 \mathrm{~kg} \mathrm{ha}^{-1}\right) \text {. }\end{array}$} \\
\hline $\begin{array}{l}\text { Customized } \\
\text { fertilizers, Moister } \\
\text { regime, Wue and } \\
\text { economics. }\end{array}$ & \\
\hline Article Info & \\
\hline $\begin{array}{l}\text { Accepted: } \\
\text { 20 February } 2017 \\
\text { Available Online: } \\
\text { 10 March } 2017\end{array}$ & \\
\hline
\end{tabular}

\section{Introduction}

Potato (Solanum tuberosum L.) ranks fourth among major food crops of the world, occupying an area of 19.26 million ha with annual production and productivity of 320.71 million tonnes and 16.64 tonnes/ha, respectively (http:// www.fao.org). Asia and Europe are the world's major potato producing regions, accounting for more than 80 per cent of world production. Irrigation and fertilization are two important inputs in potato production and increased production depends upon efficient use of irrigation water and fertilizers throughout the growth period. In the present day context, the effective and economic utilization of water and fertilizers is very essential to reduce the cost of cultivation and can best be achieved through the use of improved irrigation techniques, viz. drip, sprinkler and supplying balanced and adequate doses of fertilizers. Use of drip and sprinkler irrigation can increase the yield up to $20-40 \%$ along with water saving up to 39 $\%$ in potato crop (Pawar et al., 2002). However, their adoption is restricted mainly due to huge investment needed for installation during the initial period. Therefore, the economic feasibility of these techniques is needed to be assessed for a short-duration crop like potato. The response of applied fertilizers is also expected to vary with different methods of irrigation as frequency of water application is different in sprinkler, drip and conventional furrow irrigation system. Further, it has been reported that soil temperature causes large fluctuations in potato yield and can be manipulated to some degree by adjusting the soil moisture. High evaporation rate and low amount of rainfall 
during that period reduced the moisture from the soil surface and creates a drought like situation which reduced the yield. Potato is very sensitive to water stress and even short term water stress can cause significant reduction in yield. Therefore, irrigation based on cumulative pan evaporation will help to maintain the soil moisture without any waste of water. Keeping this in view the present study was made to find the best irrigation schedule Therefore, the present studies were conducted to evaluate variable fertilizer doses under different irrigation methods and assess the economic feasibility of these techniques.

Nutrient management being one of the most important input with sufficient available water to achieve potential yield of potato. Water is an important input for potato production and its management problem varies from irrigation to irrigation. Optimum soil moisture is needed to be maintained in root zone to meet crop requirement for higher yield. It can be achieved best through the use of drip and sprinkler irrigation system. However its adoption is restricted mainly due to high investment for short duration crop like potato, which is most sensitive to soil moisture and irrigated by underground water and which is day by day the depleting. Hence economization of water is a need of the hour.

Beside irrigation other factor is being fertility levels and among different plant nutrients nitrogen, phosphorus and potassium being most important elements for promoting growth, yield and quality of tubers in potato. Nitrogen is an essential constituent of protein and chlorophyll and found physiological importance in plant metabolism such as nucleotides, phospholipids, alkaloids, enzymes hormones and vitamin. Nitrogen promotes vegetative growth, tuber number and tuber size. It increases to considerable extent the utilization of potassium, phosphorus and other micro nutrients. Sulphur is constituent of essential amino acid, vitamin and aromatic compound and provides resistance against insect, pest and disease resistance in plants.

The phosphorus is second limiting, nutrient in potato production. Its deficiency retards the growth and leaves become dull without luster and increase tuber yield and number of medium size tuber.

Potassium is the next essential nutrient for potato production. The requirements of potato crop for potassium or higher than those of cereals. It increases the tuber yield by increasing the number of large size tuber. Micro nutrients in balanced proportion increase potato yield by retards deficiency symptoms. Potato tuber yield increased significantly by application of zinc sulphate (Neelima Joshi \& Raghav, 2005).

Besides major nutrients boron and zinc are the most important micro nutrient particularly in our country because most of Indian soils are deficient in these nutrients. Boron is essential for translocation of sugar, reproduction for IAA and other metabolic processes. Zinc is essential mineral for IAA synthesis. Zinc deficiency is closely related to the inhibition of RNA synthesis, reduces root and shoot growth and chlorophyll concentration of leaves. Zinc is directly or indirectly required by the several enzyme systems and closely involved in the nitrogen metabolism of plant.

The costs of chemical fertilizers have enormously gone up and are still on increase it is necessary to examine alternative, cheaper and easily available nutrient source to meet out fertilizer requirements.

\section{Materials and Methods}

The experiment was conducted during the winter season 2010-11 at Agronomy Research Farm, Narendra Deva University of Agriculture \& Technology, Kumarganj, 
Faizabad (U.P.). The soil of experimental field was silt loam in texture, alkaline $(\mathrm{pH}$ $8.0)$, poor in organic carbon $(0.35 \%)$ and deficient in available $\mathrm{N}(147.5 \mathrm{~kg} / \mathrm{ha})$, medium $\mathrm{P}(14.50 \mathrm{~kg} / \mathrm{ha})$ and rich $\mathrm{K}(210.1$ $\mathrm{kg} / \mathrm{ha})$. The treatments viz. two moisture regime- $0.8 \mathrm{IW} / \mathrm{CPE}$ ratio, 1.0 IW/CPE ratio with $6 \mathrm{~cm}$ irrigation water depth and six customized fertilizers viz. ICAR application $\mathrm{F}_{1}$ (N:P:K:Zn:B:S) $120: 80: 100: 2: 0: 8$, $\mathrm{F}_{2}-12: 26: 18: 1: 0: 6(\mathrm{~N}: \mathrm{P}: \mathrm{K}: \mathrm{Zn}: \mathrm{B}: \mathrm{S} 150$ : $\left.97.5: 67.5: 3.75: 0: 22.5 \mathrm{~kg} \mathrm{ha}^{-1}\right), \mathrm{F}_{3}-18: 28$ : $10: 1: 0: 6$ (N:P:K:Zn:B:S $150: 105: 37.5$ $\left.: 3.75: 0: 22.5 \mathrm{~kg} \mathrm{ha}^{-1}\right), \mathrm{F}_{4}-8: 18: 26: 1: 0.1$ : 6 (N:P:K:Zn:B:S 150 : $67.5: 97.5: 3.75$ : $\left.0.37: 22.5 \mathrm{~kg} \mathrm{ha}^{-1}\right), \mathrm{F}_{5^{-}} 8: 14: 24: 1: 0.1: 6$ (N:P:K:Zn:B:S $150: 52.5: 90: 3.75: 0.37$ : $22.5 \mathrm{~kg} \mathrm{ha}^{-1}$ ) and $\mathrm{F}_{6}-8: 12: 28: 1: 0.1: 6$ (N:P:K:Zn:B:S $150: 45: 105: 3.75: 0.37$ : $22.5 \mathrm{~kg} \mathrm{ha}^{-1}$ ). The experiment was laid out in Randomized Block Design with four replications.

All the nutrients except $\mathrm{N}$ were applied basal as per treatment except N. Nitrogen was applied in 2 splits between sowing and first and second irrigation. Sulphur, zinc and boron were applied as elemental sulphur (85\% S), zinc chloride (45\% Zn) and borax $(11 \% \mathrm{~B})$ respectively. Potato variety, 'Kufri Ashoka' was sown at spacing of $50 \mathrm{~cm} \times 20 \mathrm{~cm}$ on $9^{\text {th }}$ November in 2010-11. Weed growth was controlled by hand-weeding. All the other recommended package of practices were adopted during the crop-growth period. The crop was harvested in the first week of February, and tuber yield was recorded. After taking into consideration the variable and fixed inputs, the expenditure incurred on various inputs was worked out for each treatment. The selling price of potato was Rs. 4000/ tonnes and gross returns were calculated on the basis of this price. Benefitcost ratio was worked out for different treatments. At the end of the experiment, total amount of water applied was calculated for each irrigation treatment and the water use efficiency (tonnes $\mathrm{ha}^{-1} \mathrm{~cm}$ ) was calculated as per the formula:

Water-use efficiency $=$ Total yield of tubers (tonnes) / Total water applied (cm)

\section{Result and Discussion}

\section{Water use efficiency}

The consumptive use of water (CU) and water use efficiency (WUE) increasing with increasing nutrient proportion up to customize fertilizer $\mathrm{F}_{4}-8: 18: 26: 1: 0.1: 6$ (N:P:K:Zn:B:S $150: 67.5: 97.5: 3.75: 0.37$ : $22.5 \mathrm{~kg} \mathrm{ha}^{-1}$ ) (Table-2) Application of more nitrogen favored the growth of plants, as they consumed more amount of water for their metabolic processes and transpiration which in term led to higher consumptive use. The increase in water use efficiency with increasing nutrient level was mainly due to proportionately higher increase in tuber yield than consumption of water.

Starch content of the tuber is also affected by moisture regimes. Increasing the regimes decreased the starch content in the tuber. This reduction in starch is due to hydrolysis of starch in to sugar at higher water supply. Moreover, larger supply of moisture has increased the water content of the tuber. Pahuja and Sharma (1982) also reported similar results.

Tuber yield per unit of water applied increased significantly in case of lower moisture regime than higher regimes. $I_{2}$ moisture regime has significantly lower value of tuber yield per unit of water applied in comparison to $\mathrm{I}_{1}$ ratio (Table-1 \& 2.). Under $\mathrm{I}_{2}$ moisture regime value decreased due to fact that the water applied at this moisture regime was more than its lower level but the tuber yield differences was not so wide, the result in close conformity with the findings of Bhan and Dhama (1982), Hane and Pumphrey (1984) and Chandra et al., (2001). 
Table.1 Total tuber weight $\left(\mathrm{kg} \mathrm{plot}^{-1}\right)$ and $\left(\mathrm{q} \mathrm{ha}^{-1}\right)$ as influenced by moisture regimes and customized fertilizers

\begin{tabular}{|l|c|c|}
\hline Treatments & $\begin{array}{c}\text { Total tuber weight (kg } \\
\left.\text { plot }^{-1}\right)\end{array}$ & $\begin{array}{c}\text { Total tuber yield (q ha- } \\
\mathbf{1})\end{array}$ \\
\hline Moisture regimes & 26.42 & 220.19 \\
\hline $\mathrm{I}_{1}$ & 27.84 & 232.03 \\
\hline $\mathrm{I}_{2}$ & 0.28 & 2.39 \\
\hline SEm \pm & $\mathbf{0 . 8 2}$ & $\mathbf{6 . 9 0}$ \\
\hline CD at 5\% & \multicolumn{2}{|c|}{} \\
\hline Customized fertilizers & 23.44 & 195.36 \\
\hline $\mathrm{F}_{1}$ & 26.81 & 223.44 \\
\hline $\mathrm{F}_{2}$ & 25.30 & 210.83 \\
\hline $\mathrm{F}_{3}$ & 30.32 & 252.66 \\
\hline $\mathrm{F}_{4}$ & 27.71 & 230.89 \\
\hline $\mathrm{F}_{5}$ & 29.22 & 243.49 \\
\hline $\mathrm{F}_{6}$ & 0.49 & 4.14 \\
\hline $\mathrm{SEm} \pm$ & $\mathbf{1 . 4 3}$ & $\mathbf{1 1 . 9 6}$ \\
\hline CD at 5\% & &
\end{tabular}

Table.2 Total water received and water use efficiency as influenced by moisture regimes and customized fertilizers

\begin{tabular}{|l|c|c|}
\hline Treatments & $\begin{array}{c}\text { Total water received } \\
(\mathbf{c m})\end{array}$ & $\begin{array}{c}\text { Water use efficiency }\left(\mathbf{k g ~ h a}^{-1}\right. \\
\left.\mathbf{c m}^{-1}\right)\end{array}$ \\
\hline Moisture regimes & 16.3 & 135.0 \\
\hline $\mathrm{I}_{1}$ & 22.3 & 104.04 \\
\hline $\mathrm{I}_{2}$ & 19.3 & 101.22 \\
\hline Customized fertilizers & 19.3 & 115.77 \\
\hline $\mathrm{F}_{1}$ & 19.3 & 109.23 \\
\hline $\mathrm{F}_{2}$ & 19.3 & 130.91 \\
\hline $\mathrm{F}_{3}$ & 19.3 & 119.63 \\
\hline $\mathrm{F}_{4}$ & 19.3 & 126.16 \\
\hline $\mathrm{F}_{5}$ & \multicolumn{2}{|l|}{} \\
\hline $\mathrm{F}_{6}$ &
\end{tabular}


Table.3 Economics of different treatment combinations

\begin{tabular}{|c|c|c|c|c|}
\hline Treatments & $\begin{array}{l}\text { Gross return } \\
\left(\text { Rs. ha }{ }^{-1}\right)\end{array}$ & $\begin{array}{c}\text { Total cost of } \\
\text { cultivation }\left(\text { Rs. } \text { ha }^{-1}\right)\end{array}$ & $\begin{array}{l}\text { Net return } \\
\left(\text { Rs. ha } \text { h }^{-1}\right)\end{array}$ & B:C \\
\hline $\begin{array}{l}\mathrm{I}_{1} \mathrm{~F}_{1} \text { Irrigation at } 0.8 \text { IW/CPE ratio + ICAR application } \\
\mathrm{N}: \mathrm{P}: \mathrm{K}: \mathrm{Zn}: \mathrm{B}: \mathrm{S} 120: 80: 100: 2: 0: 8\end{array}$ & 90760 & 43468 & 47292 & 1.08 \\
\hline $\begin{array}{l}\mathrm{I}_{1} \mathrm{~F}_{2} \text { Irrigation at } 0.8 \text { IW/CPE ratio }+ \text { customize } \\
\text { fertilizer }-12: 26: 18: 1: 0: 6(\mathrm{~N}: \mathrm{P}: \mathrm{K}: \mathrm{Zn}: \mathrm{B}: \mathrm{S} 150: \\
\left.97.5: 67.5: 3.75: 0: 22.5 \mathrm{~kg} \mathrm{ha}^{-1}\right)\end{array}$ & 104000 & 43741 & 60259 & 1.37 \\
\hline $\begin{array}{l}\mathrm{I}_{1} \mathrm{~F}_{3} \text { Irrigation at } 0.8 \text { IW/CPE ratio }+ \text { customize } \\
\text { fertilizer- } 18: 28: 10: 1: 0: 6(\mathrm{~N}: \mathrm{P}: \mathrm{K}: \mathrm{Zn}: \mathrm{B}: \mathrm{S} 150: \\
\left.105: 37.5: 3.75: 0: 22.5 \mathrm{~kg} \mathrm{ha}^{-1}\right)\end{array}$ & 99040 & 43589 & 55451 & 1.27 \\
\hline $\begin{array}{l}\mathrm{I}_{1} \mathrm{~F}_{4} \text { Irrigation at } 0.8 \mathrm{IW} / \mathrm{CPE} \text { ratio }+ \text { customize } \\
\text { fertilizer }-8: 18: 26: 1: 0.1: 6(\mathrm{~N}: \mathrm{P}: \mathrm{K}: \mathrm{Zn}: \mathrm{B}: \mathrm{S} 150: \\
\left.67.5: 97.5: 3.75: 0.37: 22.5 \mathrm{~kg} \mathrm{ha}^{-1}\right)\end{array}$ & 118840 & 43841 & 74999 & 1.71 \\
\hline $\begin{array}{l}\mathrm{I}_{1} \mathrm{~F}_{5} \text { Irrigation at } 0.8 \mathrm{IW} / \mathrm{CPE} \text { ratio }+ \text { customize } \\
\text { fertilizer- } 8: 14: 24: 1: 0.1: 6(\mathrm{~N}: \mathrm{P}: \mathrm{K}: \mathrm{Zn}: \mathrm{B}: \mathrm{S} 150: \\
\left.52.5: 90: 3.75: 0.37: 22.5 \mathrm{~kg} \mathrm{ha}^{-1}\right)\end{array}$ & 108360 & 43502 & 64858 & 1.49 \\
\hline $\begin{array}{l}\mathrm{I}_{1} \mathrm{~F}_{6} \text { Irrigation at } 0.8 \mathrm{IW} / \mathrm{CPE} \text { ratio }+ \text { customize } \\
\text { fertilizer }-8: 12: 28: 1: 0.1: 6(\mathrm{~N}: \mathrm{P}: \mathrm{K}: \mathrm{Zn}: \mathrm{B}: \mathrm{S} 150: \\
\left.45: 105: 3.75: 0.37: 22.5 \mathrm{~kg} \mathrm{ha}^{-1}\right)\end{array}$ & 113320 & 43510 & 69810 & 1.60 \\
\hline $\begin{array}{l}\mathrm{I}_{2} \mathrm{~F}_{1} \text { Irrigation at } 1.0 \text { IW/CPE ratio }+ \text { ICAR } \\
\text { application N:P:K:Zn:B:S } 120: 80: 100: 2: 0: 8)\end{array}$ & 96800 & 44118 & 52682 & 1.19 \\
\hline $\begin{array}{l}\mathrm{I}_{2} \mathrm{~F}_{2} \text { Irrigation at } 1.0 \mathrm{IW} / \mathrm{CPE} \text { ratio }+ \text { customize } \\
\text { fertilizer }-12: 26: 18: 1: 0: 6(\mathrm{~N}: \mathrm{P}: \mathrm{K}: \mathrm{Zn}: \mathrm{B}: \mathrm{S} 150: \\
\left.97.5: 67.5: 3.75: 0: 22.5 \mathrm{~kg} \mathrm{ha}^{-1}\right)\end{array}$ & 110600 & 44391 & 66209 & 1.49 \\
\hline $\begin{array}{l}\mathrm{I}_{2} \mathrm{~F}_{3} \text { Irrigation at } 1.0 \mathrm{IW} / \mathrm{CPE} \text { ratio }+ \text { customize } \\
\text { fertilizer } 18: 28: 10: 1: 0: 6(\mathrm{~N}: \mathrm{P}: \mathrm{K}: \mathrm{Zn}: \mathrm{B}: \mathrm{S} 150: \\
\left.105: 37.5: 3.75: 0: 22.5 \mathrm{~kg} \mathrm{ha}^{-1}\right)\end{array}$ & 103400 & 44539 & 59161 & 1.32 \\
\hline $\begin{array}{l}\mathrm{I}_{2} \mathrm{~F}_{4} \text { Irrigation at } 1.0 \mathrm{IW} / \mathrm{CPE} \text { ratio }+ \text { customize } \\
\text { fertilizer }-8: 18: 26: 1: 0.1: 6(\mathrm{~N}: \mathrm{P}: \mathrm{K}: \mathrm{Zn}: \mathrm{B}: \mathrm{S} 150: \\
\left.67.5: 97.5: 3.75: 0.37: 22.5 \mathrm{~kg} \mathrm{ha}^{-1}\right)\end{array}$ & 123800 & 44491 & 79309 & 1.78 \\
\hline $\begin{array}{l}\mathrm{I}_{2} \mathrm{~F}_{5} \text { Irrigation at } 1.0 \mathrm{IW} / \mathrm{CPE} \text { ratio }+ \text { customize } \\
\text { fertilizer }-8: 14: 24: 1: 0.1: 6(\mathrm{~N}: \mathrm{P}: \mathrm{K}: \mathrm{Zn}: \mathrm{B}: \mathrm{S} 150: \\
\left.52.5: 90: 3.75: 0.37: 22.5 \mathrm{~kg} \mathrm{ha}^{-1}\right)\end{array}$ & 113320 & 44152 & 69168 & 1.56 \\
\hline $\begin{array}{l}\mathrm{I}_{2} \mathrm{~F}_{6} \text { Irrigation at } 1.0 \mathrm{IW} / \mathrm{CPE} \text { ratio }+ \text { customize } \\
\text { fertilizer }-8: 12: 28: 1: 0.1: 6(\mathrm{~N}: \mathrm{P}: \mathrm{K}: \mathrm{Zn}: \mathrm{B}: \mathrm{S} 150: \\
\left.45: 105: 3.75: 0.37: 22.5 \mathrm{~kg} \mathrm{ha}^{-1}\right)\end{array}$ & 120440 & 44160 & 76280 & 1.72 \\
\hline
\end{tabular}

\section{Economics}

The variation in cost of cultivation were recorded due to moisture regime, customized fertilizers, which was increased with increasing level of nutrient in customized fertilizers, irrigation are the major monitory inputs. Yield was major factor, which caused differences in net income and net return per rupee invested (Table-3).
Maximum cost of cultivation was recorded under the moisture regime of $1.0 \mathrm{IW} / \mathrm{CPE}$ ratio + customize fertilizer $\mathrm{F}_{3}-18: 28: 10: 1:$ 0 : 6 (N:P:K:Zn:B:S $150: 105: 37.5: 3.75: 0$ $: 22.5 \mathrm{~kg} \mathrm{ha}^{-1}$ ) while minimum under treatment combination of 0.8 IW/CPE + customize fertilizer ICAR application $\mathrm{N}: \mathrm{P}: \mathrm{K}: Z n: B: S 120: 80: 100: 2: 0: 8$. Maximum gross return (Rs. $123800 \mathrm{ha}^{-1}$ ) was 
recorded under the treatment combination of 1.0 IW/CPE ratio + customized fertilizers $\mathrm{F}_{4}$ $8: 18: 26: 1: 0.1: 6$ (N:P:K:Zn:B:S 150 : $\left.67.5: 97.5: 3.75: 0.37: 22.5 \mathrm{~kg} \mathrm{ha}^{-1}\right)$. The cost of cultivation was more due to more number of irrigations, higher dose of nutrient which increased cost of irrigation. Gross return was more due to higher production of tubers (Table-1\&3).

Highest net return were obtained under 1.0 IW/CPE ratio + customized fertilizers $\mathrm{F}_{4}-8$ : $18: 26: 1: 0.1: 6$ (N:P:K:Zn:B:S $150: 67.5$ : $\left.97.5: 3.75: 0.37: 22.5 \mathrm{~kg} \mathrm{ha}^{-1}\right)$ and highest benefit : cost ratio (1.78) were also recorded under the treatment combination of $\mathrm{I}_{2} \mathrm{~F}_{4} \quad 1.0$ IW/CPE ratio + customized fertilizers $\mathrm{F}_{4}-8$ : $18: 26: 1: 0.1: 6$ (N:P:K:Zn:B:S $150: 67.5$ : $\left.97.5: 3.75: 0.37: 22.5 \mathrm{~kg} \mathrm{ha}^{-1}\right)$. This was found due to low cost of irrigation and customized fertilizers (Table-3).

In conclusion every increase in the level of moisture regime increase in consumptive use of water and decrease water use efficiency. The higher water use efficiency (135.0) was recorded under $0.8 \mathrm{IW} / \mathrm{CPE}$ ratio which was more than that obtained under $\mathrm{I}_{2}$.

Minimum cost of cultivation was incurred under $\mathrm{I}_{1}$ moisture regime but maximum gross income was calculated under $\mathrm{I}_{2}$. Maximum net return and net profit per rupees was also recorded under $\mathrm{I}_{2}$. Minimum cost of cultivation was incurred under customized fertilizer $\mathrm{F}_{3}-18: 28: 10: 1: 0: 6$ (N:P:K:Zn:B:S $150: 105: 37.5: 3.75: 0$ : $22.5 \mathrm{~kg} \mathrm{ha}^{-1}$ ) but maximum gross income, net return and benefit cost ratio were computed under $\mathrm{F}_{4}-8: 18: 26: 1: 0.1: 6$ (N:P:K:Zn:B:S $150: 67.5$ : $97.5: 3.75: 0.37$ : $22.5 \mathrm{~kg} \mathrm{ha}^{-1}$ ) followed by $\mathrm{F}_{6}-8: 12: 28: 1$ : $0.1: 6$ (N:P:K:Zn:B:S 150 : $45: 105: 3.75$ : $\left.0.37: 22.5 \mathrm{~kg} \mathrm{ha}^{-1}\right)$

\section{Acknowledgement}

Sincere, thanks are due to Dr. G. R Singh Dr. B. N. Singh and Dr. R. B. Verma, NDUA\&T Faizabad U.P for his valuable guidance.

\section{References}

Bhan, S. and Dhama, C.S. 1982. Effect of frequency and method of irrigation on potato. Indian J. Agron., 27(3): 227230.

Chandra, Subhas, Singh, R.D. and Bisth, J.K. 2001. Water use and yield of potato under irrigation constraints. Annals of Agri. Res., 20(1): 128-129.

Hane, D.C. and Pumphery, F.V. 1984. Yieldevapotranspiration relationship and seasonal crop coefficient for frequently irrigated potatoes. American Potato J., 61: 661-668.

Pahuja, S.S. and Sharma, H.C. 1982. Response of potato to high soil moisture regimes, levels of nitrogen and spacing. Agri. Sci. Dig., 2(1): 32-34.

Pawar, D.D., Bhoj, P.G. and Shinde, S.H. 2002. Effect of irrigation method and fertilizer levels on yield of potato (Solanum tuberosum L.). Indian J. Agri. Sci., 72(2): 80-83.

\section{How to cite this article:}

Mohammad Irfan, B.N. Singh and Ghansyam Singh. 2017. Effect of Moisture Regime and Customized Fertilizer on Water Use Efficiency and Economics of Potato (Solanum tuberosum L.). Int.J.Curr.Microbiol.App.Sci. 6(3): 2215-2220. doi: https://doi.org/10.20546/ijcmas.2017.603.252 